\title{
Severe pulmonary stenosis in infancy and early childhood
}

\author{
IAN M. ANDERSON AND SORAYA NOURI-MOGHADDAM \\ From Westminster Hospital, London, S.W.1
}

\begin{abstract}
Twenty-six patients in infancy and early childhood with severe pulmonary valve stenosis and intact ventricular septum are reviewed. They were selected from a larger series of 112 patients with pulmonary stenosis of any degree, on account of early onset of symptoms and the severity of the stenosis proven by cardiac catheterization and angiocardiography, at operation or at necropsy. Our criteria for severity in this series were: presence of symptoms within the first two years of life ; right ventricular and right atrial hypertrophy on electrocardiography ; and right ventricular pressure equal to or higher than systemic blood pressure. The warning signs prompting valvotomy are deterioration of the following features: cyanosis and dyspnoea ; congestive cardiac failure ; tricuspid incompetence ; cardiac enlargement and pulmonary oligaemia on radiograph ; and right ventricular and right atrial hypertrophy on electrocardiography. The lives of 13 patients were saved by timely valvotomy. These patients are all well six months to six years after operation. Five patients died before any operation could be performed. Eight patients died within 48 hours of operation. Had some of these patients been operated on earlier the evidence indicates that they would have had a better prognosis. Therefore the importance of early recognition, prompt treatment, and emergency valvotomy, if necessary, is emphasized.
\end{abstract}

Severe pulmonary stenosis with intact ventricular septum and normal aortic root is a much graver condition in the first two years of life than in the older age group. In infancy and early childhood this disease is fatal unless promptly diagnosed and treated by pulmonary valvotomy. Insufficient general appreciation of this condition, despite a few reviews since 1952 (Johnson and Johnson, 1952 ; Gibson, White, Johnson, and Potts, 1954 ; Mustard, Rowe, and Firor, 1960 ; Mustard, Jain, and Trusler, 1968; Luke, 1966; Gersony, Bernhard, Nadas, and Gross, 1967) has prompted an analysis of 26 such patients.

In this department between 1947 and 1968 there have been 112 children with proven pulmonary stenosis. The criteria we used for severe pulmonary stenosis were $(a)$ the presence of relevant symptoms; (b) electrocardiographic evidence of right ventricular pressure either above $75 \mathrm{~mm} . \mathrm{Hg}$ or more than the systemic blood pressure. Forty six patients fitted into the severe category. Twenty six of these presented during the first two years of life: this we shall refer to as 'the early severe group'. The remaining 20 presented between the age of 2 and 13 years; these are designated 'the late severe group'.
We are discussing only the early severe group in detail because only in this group did fatalities occur. Of the late severe group 18 patients have undergone successful elective pulmonary valvotomy and are well; a further two patients await operation. There have been many reviews of pulmonary stenosis in this older age group (Brock, 1948, 1949, 1961 ; Allanby and Campbell, 1949 : Abrahams and Wood, 1951 ; Gibson et al., 1954 ; Dilley, Longmire, and Maloney, 1963 ; Engle, Ito, 을 and Goldberg, 1964 ; Lillehei, Simmons, and Todd, $>$ 1965 ; Moller and Adams, 1965 ; Tandon, Nadas, 으․ and Gross, 1965 ; Braimbridge, Oakley, Bentall, N and Cleland, 1966; Hardy, Timmis, Webb, Watson, and Blake, 1966).

\section{CLINICAL MATERIAL}

The early severe group consisted of 16 boys and 10 girls with severe pulmonary valve stenosis with $\stackrel{?}{+}$ or without infundibular hypertrophy. Their ages 0 at the time of operation or death ranged from $\bar{O}$ 3 days to 4 years with a median age of 14 months $\stackrel{\mathbb{D}}{\stackrel{D}{ }}$ (Fig. 1). Twenty four patients developed symptoms $\overrightarrow{\mathbb{D}}$ of severe pulmonary stenosis between birth and $\frac{\varrho}{\sigma}$ the end of the second year of life (Fig. 2). In one 
patient (case 3) no history was available but she seems to have had few symptoms, and in another (case 15), although there were no symptoms there was clinical and electrocardiographic evidence of severe right ventricular hypertrophy at the age of 1 year.

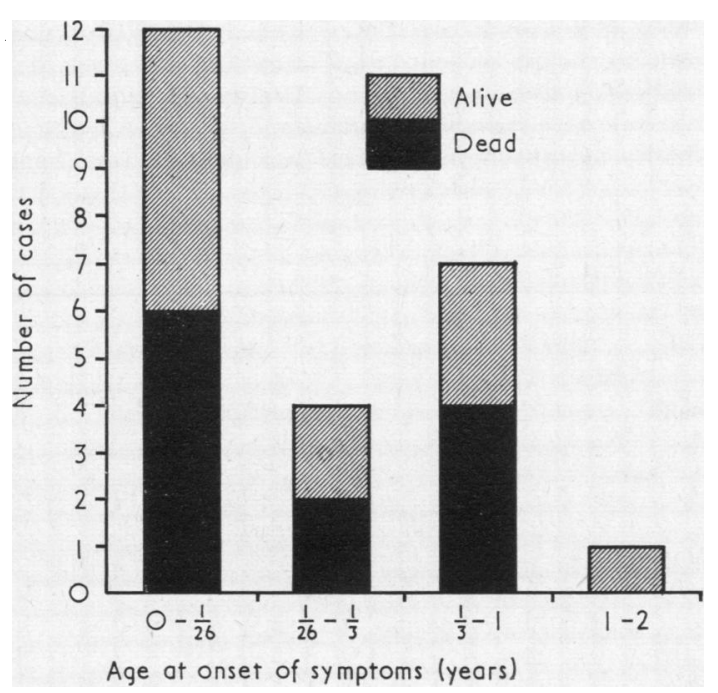

FIG. 1. Age at onset of symptoms
All 26 patients had serial electrocardiography and chest radiography pre-operatively, and the survivors post-operatively ; 21 patients had cardiac catheterization and/or angiocardiography of whom one (case 7) had cardiac catheterization between two pulmonary valvotomies during the first year of life and one (case 17) had venous angiocardiography in 1956. Five patients died before they could be fully investigated or operated on. Twenty one were operated

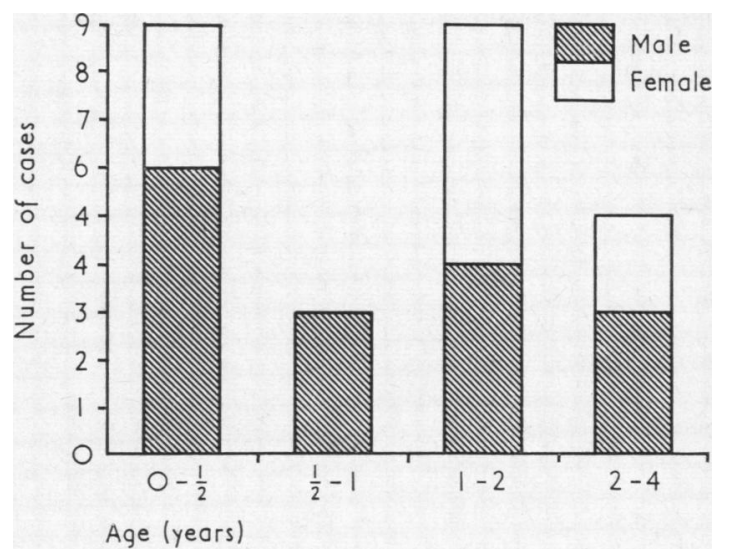

FIG. 2. Age and sex distribution

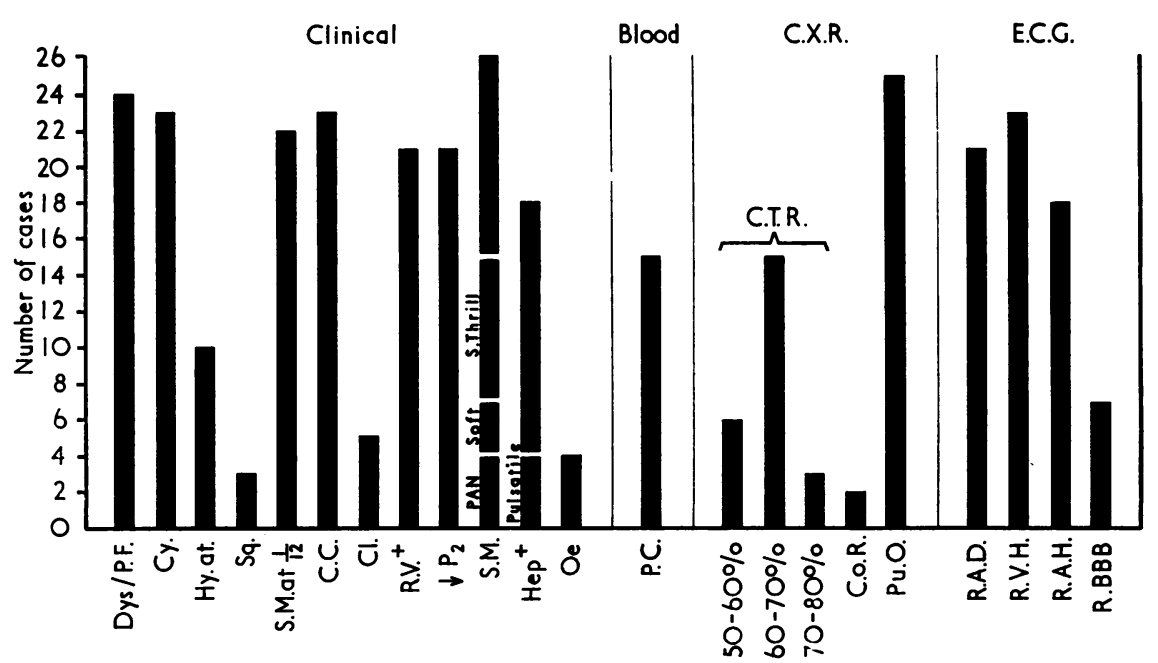

FIG. 3. Features of severe pulmonary stenosis in 26 infants and young children. Dys = dyspnoea; Cy=cyanosis; Hy.at = hypoxic attacks; Sq. = squatting; S.M.at 1/12 = history of systolic murmur heard in first month of life; C.C. = central cyanosis; $C l .=$ clubbing $; R . V .=$ right ventricular apical impulse; $\downarrow P 2=$ diminished/absent pulmonary second sound; S.M. = systolic murmur; PAN = pan-systolic murmur; Hep = hepatomegaly; Oe=oedema; P.C. = polycythaemia $; C . X . R .=$ chest $x$-ray; C.T.R. = cardiothoracic ratio; C.o.R. = cardiomegaly on record; Pu.O. = pulmonary oligaemia; E.C.G. = electrocardiogram; R.A.D. = right axis deviation; R.V.H.= right ventricular hypertrophy; R.A.H. = right atrial hypertrophy; R.BBB = right bundle-branch block. 
on, of whom one was submitted to operation without angiocardiography as he was too ill for this investigation. Thirteen patients are alive and well and have been followed up for up to six years after operation at 3-12 monthly intervals. Four of the older patients have had cardiac catheterization and angiocardiography since their operation.

\section{CLINICAL FEATURES}

A summary of each patient is shown in Table I.
The incidence of the various clinical features of this condition in our series is shown in Figure 30 Dyspnoea and/or feeding difficulty was the mose frequent manifestation, and was present in $24 \sqrt{5}$ patients. Twenty-three patients had obvious centra局 cyanosis. One patient (case 11) had severe periphera? cyanosis; his arterial oxygen saturation at cardia w catheterization was $99 \%$ and he had no finger club $\overrightarrow{0}$ bing at 3 years of age. There was a history of hypoxic attacks in 10 patients and 'squatting' in three. Fiv $\vec{\xi}$ patients had finger clubbing. The cardiac impulse was recorded as right ventricular in 21 cases. All patients had a systolic murmur. This was described as "harsh

T A B L E I

CLINICAL SUMMARY

\begin{tabular}{|c|c|c|c|c|c|c|c|c|c|}
\hline $\begin{array}{l}\text { Case } \\
\text { No. }\end{array}$ & $\begin{array}{l}\text { Date of } \\
\text { Birth }\end{array}$ & $\begin{array}{l}\text { Age at } \\
\text { Onset of } \\
\text { Symptoms }\end{array}$ & $\begin{array}{l}\text { Catheter } \\
\text { Date }\end{array}$ & $\begin{array}{l}\text { Date of } \\
\text { Opera- } \\
\text { tion }\end{array}$ & Method & $\begin{array}{c}\text { Age at } \\
\text { Operation }\end{array}$ & $\begin{array}{l}\text { Date of } \\
\text { Death }\end{array}$ & Anatomy & Remarks \\
\hline 1 & 18. 5.61 & 1 week & 20.11 .62 & 30.11 .62 & Supra V. & 17 months & - & P.V.S., P.F.O. & T.I. Good result \\
\hline 2 & 13. 4.57 & 6 months & $\begin{array}{l}\text { 20. } 7.64 \\
24.3 .61\end{array}$ & 28. 8.61 & Prof. hypo. & 4 yrs 4 mo. & 28. 8.66 & P.V.S., I.S., P.F.O. & R.V. ${ }^{++}$Small cavity \\
\hline 3 & 19. 9.67 & No history & 5. 8.49 & - & Int. resect. & - & 13. 8.49 & $\begin{array}{l}\text { P.V.S. No P.F.O. } \\
\text { recorded }\end{array}$ & $\begin{array}{l}\text { Symptomless on admission. } \\
\text { Died a few hours after }\end{array}$ \\
\hline $\begin{array}{l}4 \\
5\end{array}$ & $\begin{array}{r}7.9 .63 \\
30.11 .61\end{array}$ & $\begin{array}{l}3 \text { days } \\
1 \text { st year }\end{array}$ & $\begin{array}{l}20.11 .63 \\
30.11 .61\end{array}$ & $\begin{array}{l}28.11 .63 \\
14.12 .61\end{array}$ & $\begin{array}{l}\text { Supra V. } \\
\text { Prof. hypo. } \\
\text { Supra V. }\end{array}$ & $\begin{array}{l}2 \text { yrs } 1 \text { mo. } \\
21 \text { months }\end{array}$ & $14 . \overline{12.61}$ & $\begin{array}{l}\text { P.V.S., I.S., P.F.O. } \\
\text { P.V.S., I.S., P.F.O. }\end{array}$ & $\begin{array}{l}\text { Severe T.I. Good result } \\
\text { R.V.++ Small cavity }\end{array}$ \\
\hline 6 & 18. 2.60 & 6 months & 1. 2.61 & 5. 6.61 & $\begin{array}{l}\text { Inf. resect. } \\
\text { Prof. hypo. } \\
\text { Supra V. }\end{array}$ & $1 \mathrm{yr} .4 \mathrm{mo}$ & 5. 6.61 & P.V.S., P.F.O. & R.V.++ Small cavity \\
\hline 7 & 23. 6.63 & Birth & 5. 5.64 & $\begin{array}{l}\text { 11. } 7.63 \\
21.5 .64\end{array}$ & Brock's & $\begin{array}{l}1 \text { month } \\
11 \text { months }\end{array}$ & 22. 5.64 & P.V.S., I.S., P.F.O. & $\begin{array}{l}\text { Severe T.I. Endocardia } \\
\text { fibroelastosis and small } \\
\text { R.V. cavity }\end{array}$ \\
\hline 8 & 4. 4.64 & 6 months & 12. 5.65 & 7. 9.67 & Supra V. & 3 yrs 5 mo. & & P.V.S., P.F.O. Thin, & Good result \\
\hline 9 & 15.12 .63 & 4 months & - & 29. 8.64 & Brock's & 8 months & 29. 8.54 & P.V.S. No P.F.O. & $\begin{array}{l}\text { Severe T.I. Nephrotic syn } \\
\text { drome }\end{array}$ \\
\hline 10 & 10. 1.67 & Birth & 28. 2.67 & 9. 3.67 & Brock's & 8 weeks & - & $\begin{array}{l}\text { P.V.S. Very small } \\
\text { P.A. }\end{array}$ & Good result. No murmur \\
\hline 11 & 26. 8.60 & Birth & 30. 4.63 & 30. 5.63 & Supra V. & 2 yrs 4 mo. & - & $\begin{array}{l}\text { P.V.S., I.S. No } \\
\text { P.F.O. recorded }\end{array}$ & Severe T.I. \\
\hline 12 & 27. 8.59 & 5 months & 14. 6.61 & 20.11 .61 & Supra V. & 2 yrs 3 mo. & - & $\begin{array}{l}\text { P.V.S. No P.F.O. } \\
\text { recorded }\end{array}$ & $\begin{array}{l}\text { Good result. E.C.G. sligh } \\
\text { deterioration since } 5 \text { yrș } \\
\text { post-op. }\end{array}$ \\
\hline 13 & 29. 8.65 & 3 months & - & 一 & - & 一 & 6. 1.66 & P.V.S., P.F.O. & $\begin{array}{l}\text { Died of severe anoxic } \\
\text { attacks while being re } \\
\text { ferred here }\end{array}$ \\
\hline 14 & 27. 6.64 & $\begin{array}{l}\text { Within 1st } \\
\text { month }\end{array}$ & $\begin{array}{l}11.8 .64 \\
15.11 .67\end{array}$ & 21. 4.66 & Brock's & 22 months & - & P.V.S., P.F.O. & $\begin{array}{l}\text { Good result. Mean fronta } \\
\text { Q.R.S. axis not changed. } \\
\text { Still moderate P.S. }\end{array}$ \\
\hline 15 & 15. 3.65 & - & 15. 2.67 & 20. 2.67 & Supra V. & 23 months & 一 & $\begin{array}{l}\text { P.V.S. No P.F.O. } \\
\text { recorded }\end{array}$ & $\begin{array}{l}\text { Asymptomatic with R.V } \\
\text { pressure } 122 /-4 \text {. Good } \\
\text { result }\end{array}$ \\
\hline 16 & 11. 4.66 & 1 month to & 2.10 .67 & 9.10 .67 & Supra V. & 18 months & & P.V.S., P.F.O. & Good result \\
\hline 17 & 14. 9.55 & 3 days & 24. 2.56 & - & - & - & 27. 2.55 & P.V.S., P.F.O. & $\begin{array}{l}\text { Venous angiogram. Died of } \\
\text { inhalation of gastric cons } \\
\text { tent }\end{array}$ \\
\hline 18 & 26. 4.67 & 3-4 months & 13. 9.67 & 21. 9.67 & Supra V. & 5 months & - & P.V.S., P.F.O. & $\begin{array}{l}\text { Good result. Short pulmon } \\
\text { ary diastolic murmur }\end{array}$ \\
\hline $\begin{array}{l}19 \\
20\end{array}$ & $\begin{array}{r}\text { 3. } 7.66 \\
10.4 .68\end{array}$ & $\begin{array}{l}\text { Birth } \\
\text { Birth }\end{array}$ & $\begin{array}{l}\text { 23. } 5.68 \\
\text { 19. } 4.68\end{array}$ & $\begin{array}{l}\text { 27. } 5.68 \\
\text { 19. } 4.68\end{array}$ & $\begin{array}{l}\text { Supra V. } \\
\text { Brock's }\end{array}$ & $\begin{array}{l}1 \mathrm{yr} .10 \mathrm{mo} . \\
9 \text { days }\end{array}$ & 19. $\overline{4} .68$ & $\begin{array}{l}\text { P.V.S. } \\
\text { P.V.S. }\end{array}$ & $\begin{array}{l}\text { T.I. Good result } \\
\text { Fibroelastosis of R.V. Car } \sigma \\
\text { diac arrest at operation }\end{array}$ \\
\hline $\begin{array}{l}21 \\
22\end{array}$ & $\begin{array}{r}\text { 2. } 5.66 \\
19.7 .68\end{array}$ & $\begin{array}{l}\text { Birth } \\
\text { Birth }\end{array}$ & $22 . \overline{7} .68$ & 22. $\overline{7} .68$ & Brock's & 3 days & $\begin{array}{l}\text { 14.10.67 } \\
22.7 .68\end{array}$ & $\begin{array}{l}\text { P.V.S. No P.F.O. } \\
\text { Very severe P.V.S. }\end{array}$ & $\begin{array}{l}\text { Died of bronchopneumonia } \\
\text { Catheter diagnosis pulm } \\
\text { atresia. T.I. }\end{array}$ \\
\hline 23 & 5. 9.67 & Birth & 2. 4.68 & 11. 4.68 & Supra V. & 6 months & 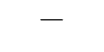 & P.V.S., P.F.O. & $\begin{array}{l}\text { Coeliac disease. T.I. Goods } \\
\text { result }\end{array}$ \\
\hline 24 & 11. 8.67 & Birth & - & - & 一 & - & 一 & No P.F.O. & $\begin{array}{l}\text { Died of hypoxic attacks and } \\
\text { acute suppurative bron } \\
\text { chitis }\end{array}$ \\
\hline $\begin{array}{l}25 \\
26\end{array}$ & $\begin{array}{r}30.10 .66 \\
4.7 .68\end{array}$ & $\begin{array}{l}1 \text { st year } \\
2 \text { weeks }\end{array}$ & $\begin{array}{l}22.11 .67 \\
30.7 .68\end{array}$ & $\begin{array}{l}30.11 .67 \\
24.8 .68\end{array}$ & $\begin{array}{l}\text { Supra V. } \\
\text { Brock's }\end{array}$ & $\begin{array}{l}13 \text { months } \\
6 \text { weeks }\end{array}$ & 24. $\overline{8} .68$ & $\begin{array}{l}\text { P.V.S., P.F.O. } \\
\text { P.V.S. and deform- } \\
\text { ity. Bilocular R.V. }\end{array}$ & $\begin{array}{l}\text { Good result } \\
\text { Cystic and dysplastic } \\
\text { kidney. Renal failure }\end{array}$ \\
\hline
\end{tabular}

Supra V.= supravalvular valvotomy; P.V.S. = pulmonary valve stenosis; P.F.O.=patent toramen ovale; T.I. $=$ tricuspid incompetence Prof. hypo. $=$ profound hypothermia; Inf. resect. $=$ infundibular resection; I.S. $=$ infundibular stenosis; R.V. $+t=$ severe right ventricula hypertrophy; Brock's = transventricular valvotomy; P.A. = pulmonary artery 


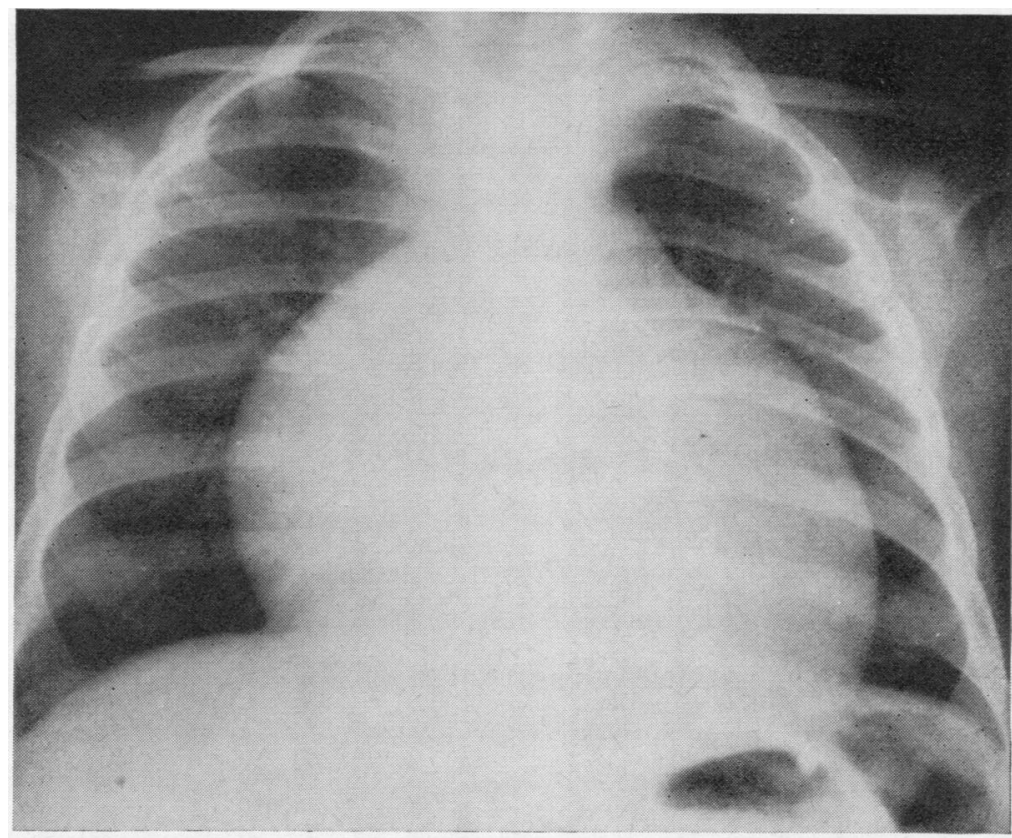

(a)

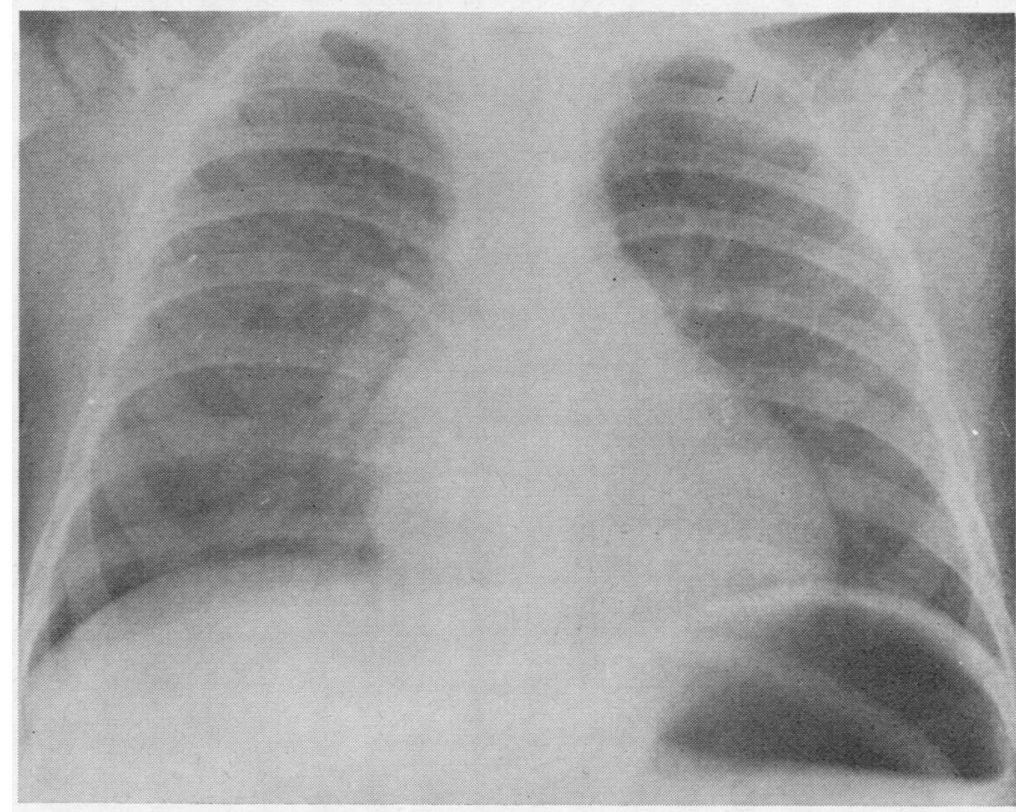

(b)

FIG. 4. Case 16. Chest radiographs (a) before operation, showing a globular, large heart and pulmonary oligaemia; (b) one year after operation, showing normal heart size and contour and normal lung vascularity. 


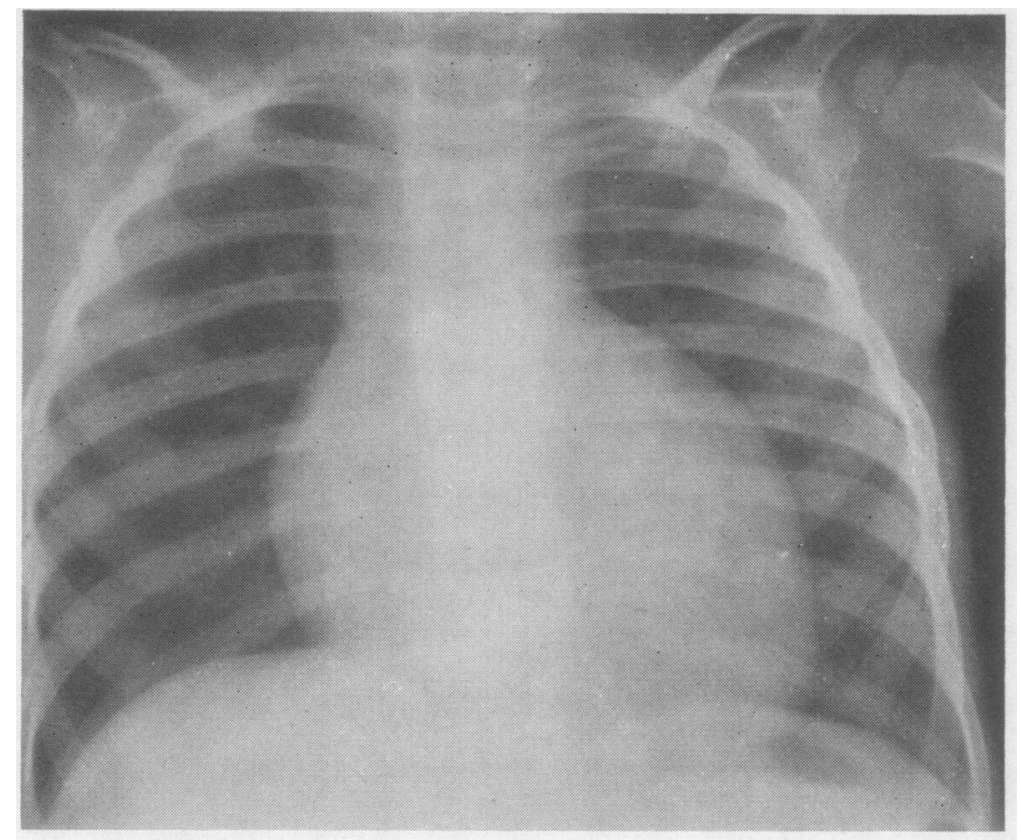

(a)

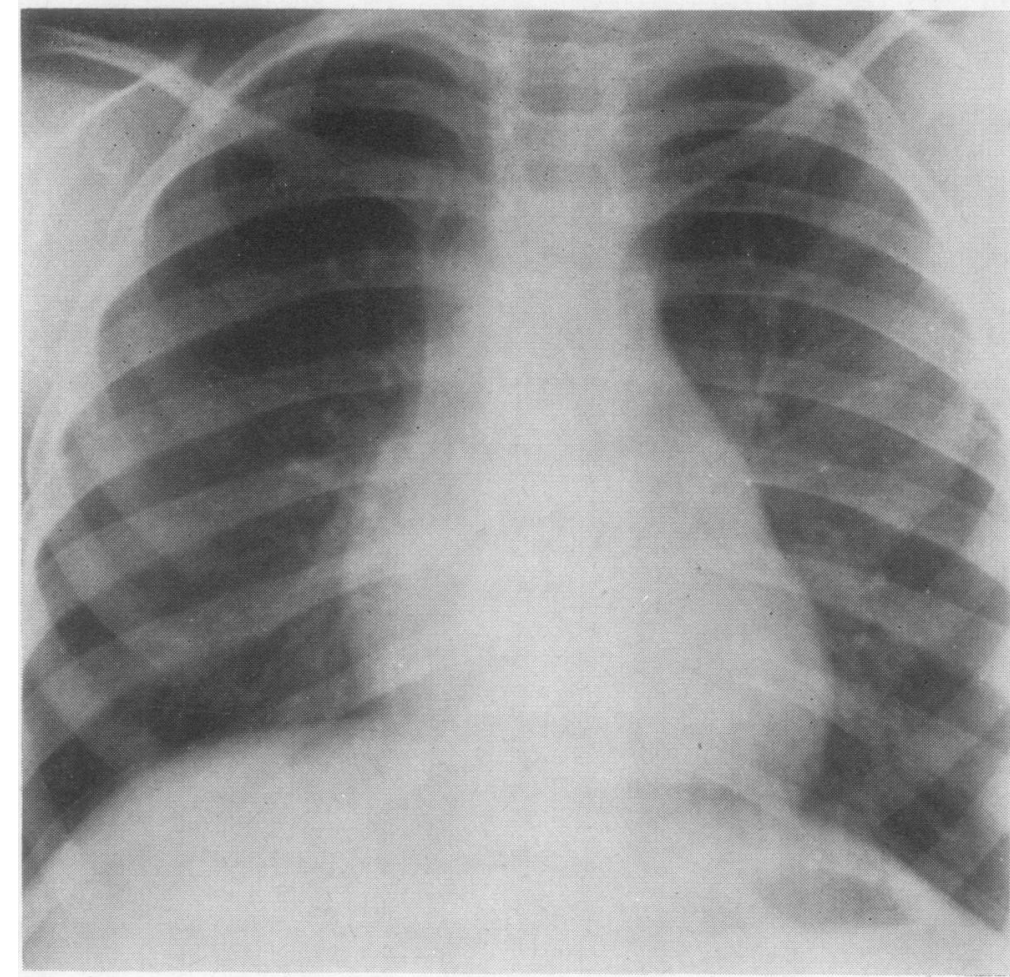

FIG. 5. Case 14. Chest radiographs (a) before operation, showing a large globular heart and oligaemia; $(b)$ two and a half years after operation, showing marked improvement, but this patient still has moderate pulmonary valve stenosis. 


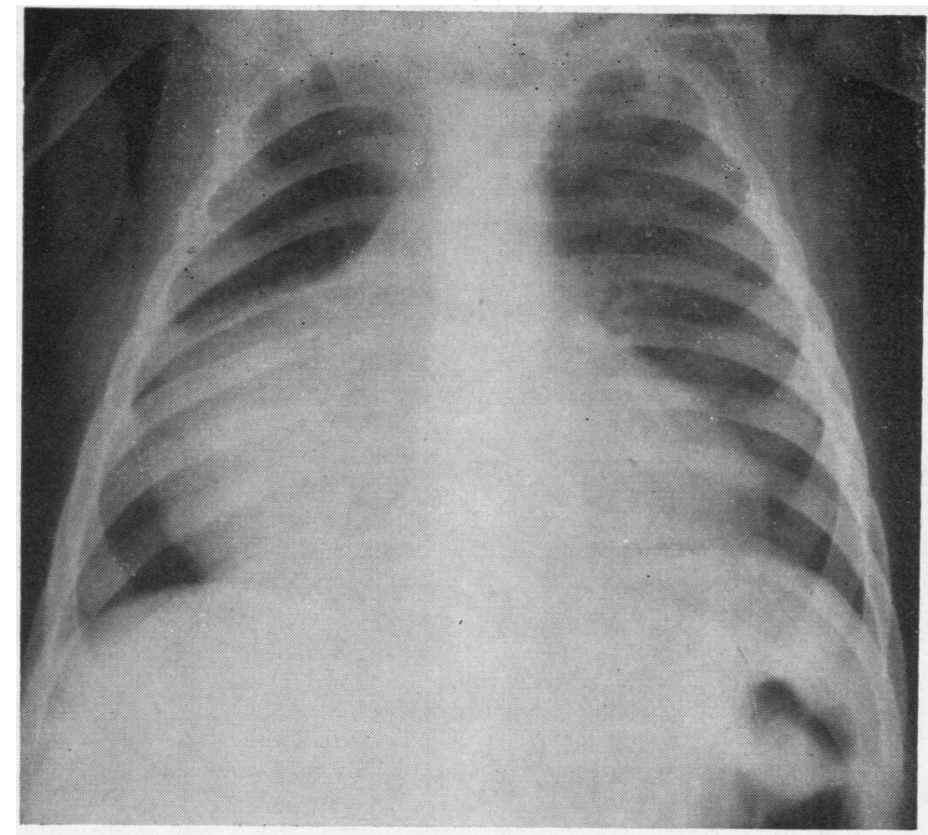

(a)

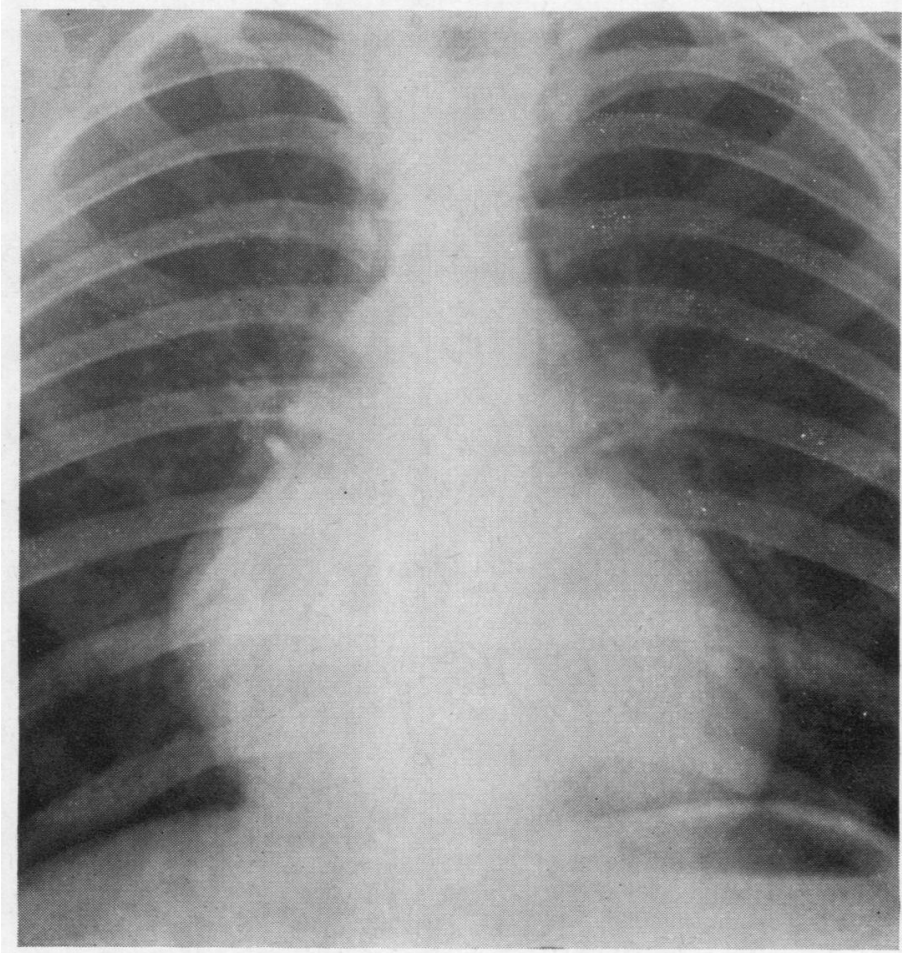

(b)

FIG. 6. Case 1. Chest radiographs (a) before operation showing a large right atrium; (b) five and a half years after operation; right atrium is much smaller but is still rather large; there is also minimal pulmonary oligaemia. 
and maximal in the pulmonary area in 19 cases, eight of whom also had a systolic thrill. Seven patients had a systolic murmur at the left 3rd and 4th intercostal spaces. In three of these patients the murmur was pan-systolic. Four of these seven were noted to have tricuspid incompetence as evidenced clinically by a pulsating liver and confirmed by angiocardiography. The pulmonary second sound was diminished or absent in 21 cases. Hepatomegaly was noted in 18 patients, including the four who had a pulsatile liver. Obvious oedema was present in five cases, one of whom (case 9) had the nephrotic syndrome. Twenty-three patients developed right heart failure prior to operation.

PRE-OPERATIVE INVESTIGATIONS Thirteen patients had polycythaemia (haemoglobin more than $16.5 \mathrm{~g}$./ $100 \mathrm{ml}$.) and all these patients were cyanosed.
Radiology. All patients had cardiac enlargement, $\vec{\Rightarrow}$ mostly of globular configuration (Figs $4 a$ and $5 a): \stackrel{?}{+}$ 25 patients had definite pulmonary oligaemia and 160 had right atrial enlargement (Fig. 6a). In one patient흐 no chest film was available.

Electrocardiography Typical appearances are shown $\stackrel{\Phi}{\varnothing}$ in Figs $7 \mathrm{a}$ and $8 \mathrm{a}$; these rapidly increased in severity (Fig. 7b). The relevant electrocardiographic data are $\vec{A}$ shown in Table II. Twenty patients had evidence of ${ }_{-}^{\circ}$ right ventricular hypertrophy as defined by Nadas $\vec{\omega}$ (1963). These had $R$ waves in leads $V_{1}$ or $V_{2}\left(R V_{1} A\right)$. $\omega_{2}$ taller than the average normal for their age $\left(R V_{1} E\right)+$ (Fig. 9a). Also the depth of $S$ in $V_{1}$ was less and $S_{i}^{x}$ in $V_{5}$ more than expected for their age. Electrocardio- $A$ grams of three patients were missing but were reportedicu to have shown right ventricular hypertrophy and ${ }^{\omega}$ right axis deviation. Twenty-one patients had right ${ }^{N}$

\section{[a]}

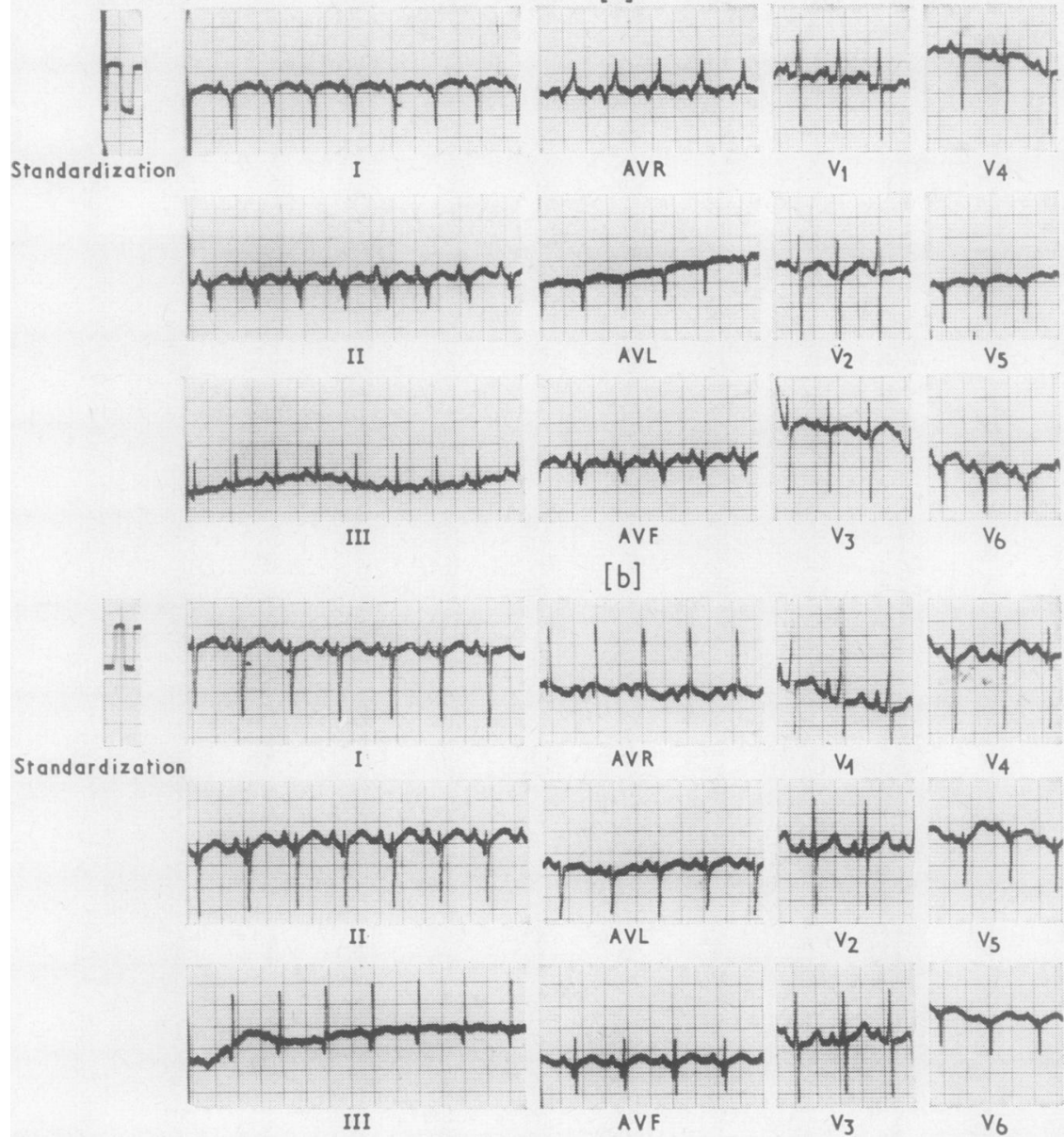

FIG. 7. Case 21. Electrocardiograms (a) at 1 week of age showing tall peaked PII and clockwise rotation but no $\mathbb{D}_{\mathbb{B}}$ much right ventricular hypertrophy. Leads $V_{2}$ to $V_{5}$ are at half standard; $(b)$ at 3 months of age showing markedo deterioration and right ventricular hypertrophy. Leads $V_{2}$ to $V_{8}$ are at half standard. 
[a]

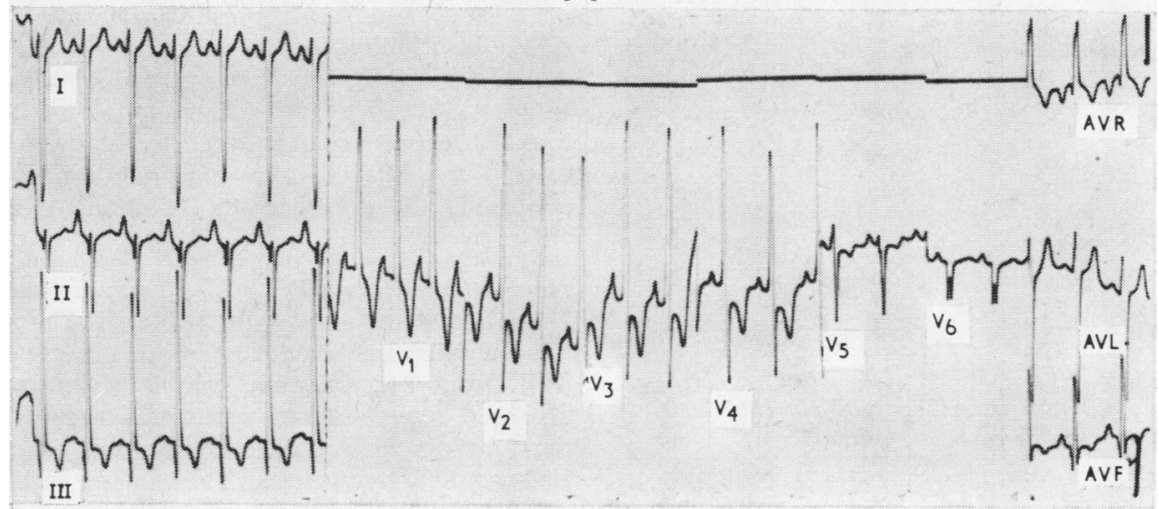

[b]
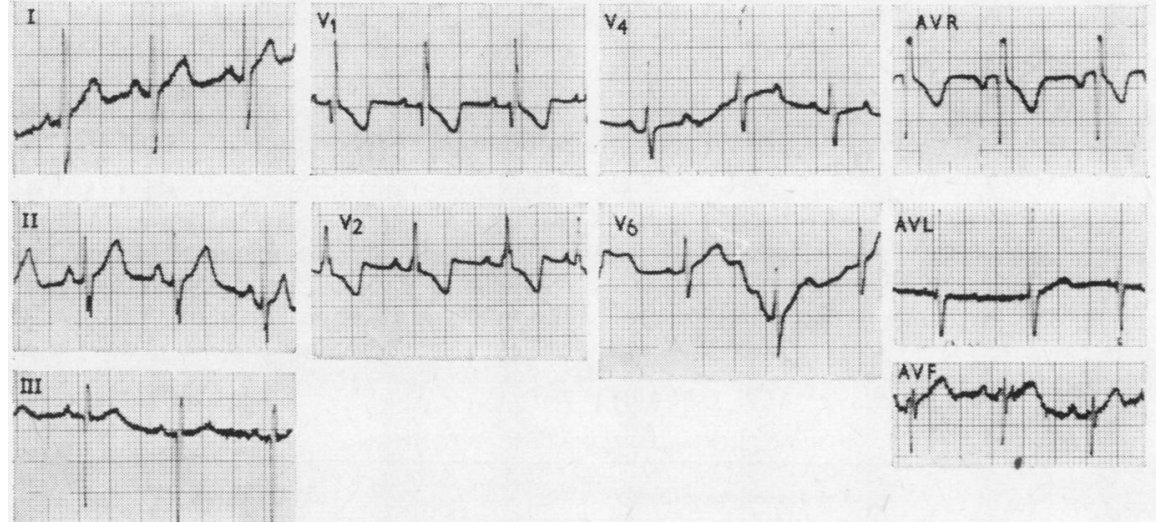

FIG. 8. Case 16. Electrocardiograms (a) before operation; (b) eight months after operation.

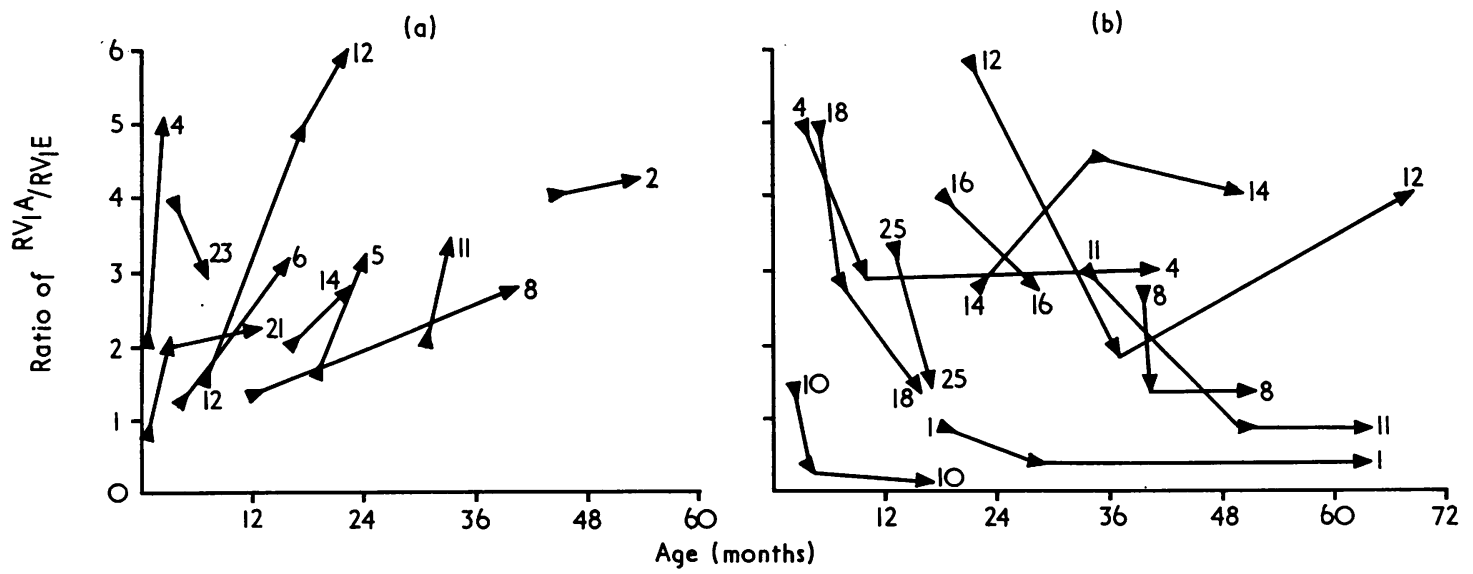

FIG. 9. Pre-operative (a) and post-operative (b) E.C.G. progress. $R V_{1} A=$ actual height of $R$ in $V_{1}$ (mm.); $R V_{1} E=$ average normal height of $R V_{1}$; the numbers on the arrows indicate the case numbers. 
axis deviation (mean QRS axis in frontal plane more than $+100^{\circ}$ ) (Fig. 10). Sixteen had right atrial hypertrophy (PII peaked and taller than $3 \mathrm{~mm}$.). Seven patients had right bundle-branch block. Seventeen patients had ST depression and $\mathrm{T}$-wave inversion beyond lead $V_{3}$.
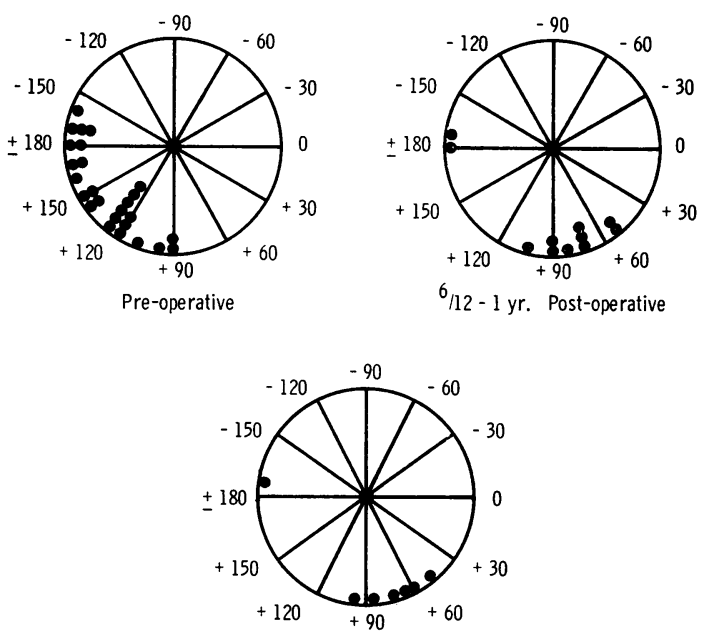

Last Visit $1 \frac{1}{2}-6$ years Post-operative

FIG. 10. Mean $Q R S$ axis in the frontal plane in preand post-operative cases.
Patients 1, 7, 10, and 22, in whom the $R V_{1} A$ was of normal amplitude, presumably had a diminutive right ventricular cavity (Benton, Elliott, Adams, Anderson, Hong, and Lester, 1962 ; Williams, BarrattBoyes, and Lowe, 1963 ; Gersony et al., 1967). Cases 1 and 10 improved post-operatively and are well, but cases 7 and 22 died following operation, and necropsy confirmed the presence of a diminutive right ventricular cavity.

Haemodynamic studies The haemodynamic data in 20 patients are shown in Table III. Nineteen cases had elevated right ventricular pressure. Of 11 patients in whom the systemic blood pressure was also obtained nine had right ventricular pressures higher than the systemic and two had equal pressures in the right and left ventricles. Thirteen cases had elevated right atrial pressure, 12 of whom had prominent ' $a$ ' waves. Angiocardiography showed pulmonary valve stenosis in 21 cases with a narrow jet of blood being ejected through a pin-hole pulmonary valve orifice (Fig. 11a). Associated infundibular hypertrophy was present in five cases. There were no cases of isolated infundibular stenosis.

OPERATION METHODS AND RESULTS Twenty-one patients had pulmonary valvotomy between 1961 and 1968, using different methods (Table IV).

The first three patients in 1961 had profound hypothermia and supravalvular valvotomy; in two patients infundibular resection was also performed.

T A B L E I I

ELECTROCARDIOGRAPHIC FINDINGS

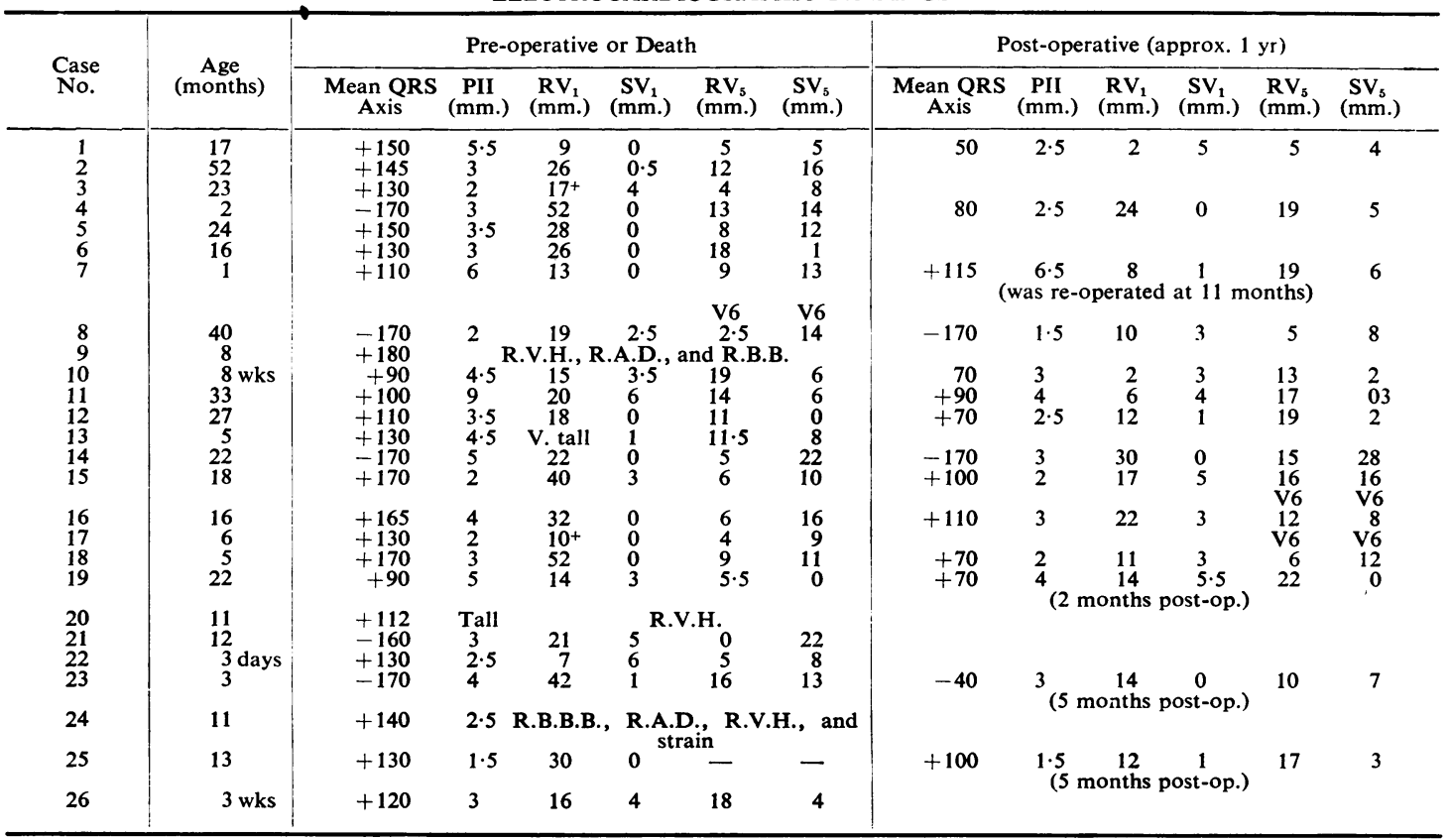

R.V.H. = right ventricular hypertrophy; R.A.D. = right axis deviation; R.B.B.B. $=$ right bundle-branch block. 


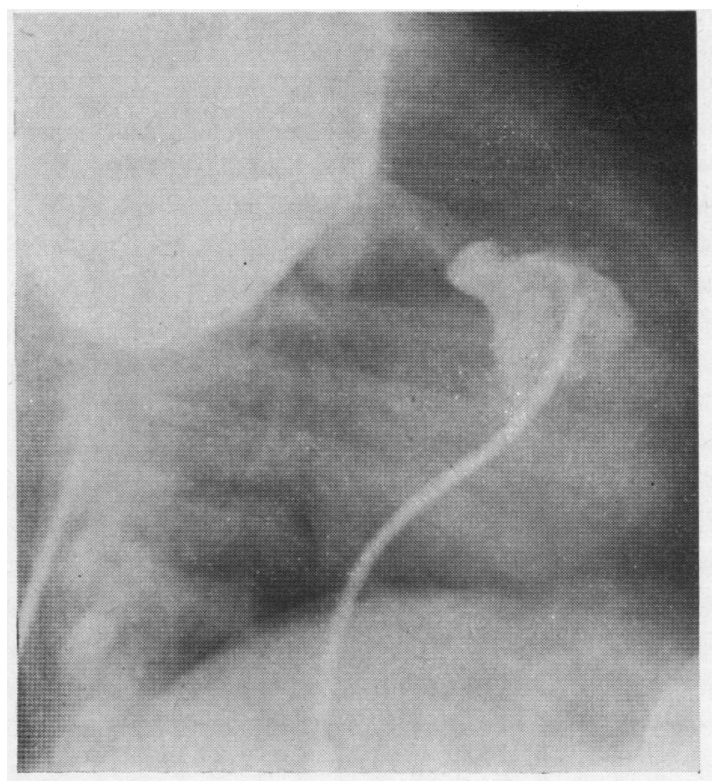

(a)

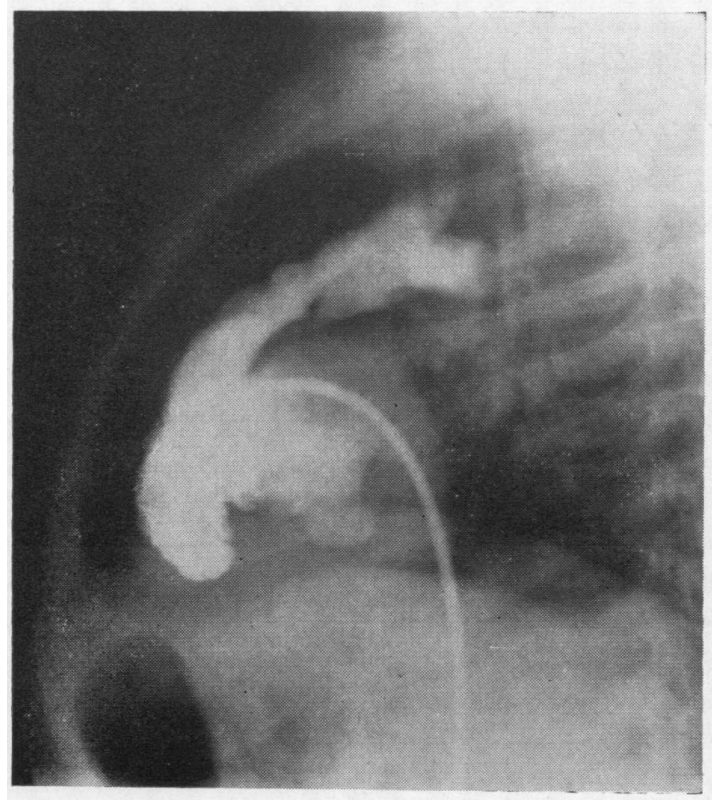

(b)

FIG. 11. Case 4. Angiocardiograms (a) before operation, showing a narrow jet through a 'pinhole' pulmonary valve; (b) one year after operation; the pulmonary valve is much wider, but the cusps are irregular and there appears to be a mild degree of pulmonary stenosis.
These three patients all died, and at necropsy were found to have severe right ventricular hypertrophy obliterating the right ventricular cavity to a degree which was thought to be incompatible with life (Table V).

The remaining patients since 1962 have been operated on under normothermic conditions. A right ventricular bypass was held in readiness for resuscitation in case of cardiac difficulties during the operation. A median sternotomy was done in all cases. Where possible, i.e., in 11 patients, venous inflow occlusion and supravalvular pulmonary valvotomy was carried out. All these patients are alive and well, with remarkable improvement in their clinical state, electrocardiogram, and chest film. The youngest patient treated by this method was 2 months old.

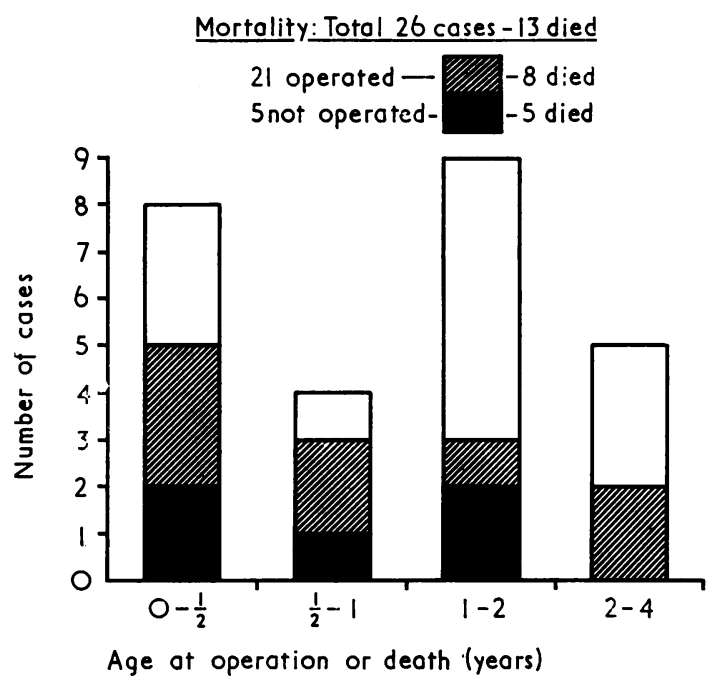

FIG. 12. Pre-and post-operative mortality.

There were seven patients in whom transventricular valvotomy was attempted because the pulmonary artery was considered too small for the supravalvular method. The youngest was 3 days old. Five of these died soon after operation; one patient (case 14) improved but still has a moderate degree of pulmonary stenosis; and one patient (case 10) has made very good progress. Of those who died, one patient (case 7) had two operations, at 1 and 11 months of age. Necropsy showed hypoplasia of the right ventricle and pulmonary artery with right ventricular fibroelastosis. One infant (case 9) had a severe nephrotic syndrome at 8 months of age, and was unconscious before operation. Although the pulmonary oligaemia improved radiologically, consciousness was never regained. Another infant (case 20), who was operated on at 3 days and died, had endocardial fibroelastosis. Case 22 improved very much after operation on the third day of life and was pink, but died the following day of milk inhalation. Case 26 had severe cardiac and renal failure and a dys- 
T A B L E I I I

PRE-OPERATIVE CATHETERIZATION DATA

\begin{tabular}{|c|c|c|c|c|c|c|c|}
\hline \multirow[b]{2}{*}{ Case No. } & \multirow{2}{*}{$\begin{array}{c}\text { Age at } \\
\text { Catheterization }\end{array}$} & \multicolumn{4}{|c|}{ Pressures } & \multicolumn{2}{|c|}{ Oxygen Saturation \% } \\
\hline & & R.V. & P.A. & R.A. & L.V. or F.A. & $\begin{array}{l}\text { Mixed } \\
\text { Venous }\end{array}$ & Arterial \\
\hline $\begin{array}{l}1 \\
2\end{array}$ & $\begin{array}{l}17 \text { months } \\
4 \text { years }\end{array}$ & $\begin{array}{c}81 / 0 \\
130 /-5\end{array}$ & $\overline{6 / 0}$ & $\begin{aligned} a & =3 \cdot 5 \\
m & =+1\end{aligned}$ & $\stackrel{78 / 0}{-}$ & $\begin{array}{l}70 \\
74\end{array}$ & $\stackrel{87}{{ }^{8 .}} 98$ \\
\hline 4 & 2 months & $120 / 0$ & - & $\begin{array}{l}\mathrm{a}=13 \\
\mathrm{~m}=+6.5\end{array}$ & $84 / 44$ & 28 & 56 \\
\hline 5 & 2 years & $150 / 5$ & & $\begin{aligned} \mathrm{m} & =+0.5 \\
\mathrm{a} & =5 \\
\mathrm{~m} & =+1\end{aligned}$ & $80 / 10$ & 62 & 86 \\
\hline 6 & 1 year & $120 /-15$ & & $\begin{aligned} v & =8 \\
\mathrm{a} & =5 \\
\mathrm{~m} & =+3\end{aligned}$ & 120 syst. & 62 & 93 \\
\hline 7 & 11 months & $\begin{array}{l}84 / 5 \\
\text { Inf. } 64 / 4\end{array}$ & & $\begin{aligned} \mathrm{a} & =12 \\
\mathrm{~m} & =+8\end{aligned}$ & - & 29 & 58 \\
\hline 8 & 1 year & $88 / 0$ & $34 / 4$ & $\begin{aligned} \mathrm{a} & =11 \\
\mathrm{~m} & =+8\end{aligned}$ & & 64 & 98 \\
\hline 10 & 8 weeks & $73 / 0$ & - & $\begin{aligned} \mathrm{a} & =14 \\
\mathrm{~m} & =+6.5\end{aligned}$ & $46 / 0$ & 34 & 44 \\
\hline 11 & 32 months & $174 / 0$ & - & $\begin{aligned} a & =25 \\
m & =+16\end{aligned}$ & $166 / 90$ & & 99 \\
\hline 12 & 22 months & $115 / 25$ & $24 / 14$ & $\begin{array}{l}\mathrm{a}=3 \\
\mathrm{v}=6\end{array}$ & $108 / 75$ & 65 & 96 \\
\hline 14 & 2 months & $36 / 0$ & - & $\begin{aligned} \mathrm{m} & =++2 \cdot 3 \\
\mathrm{a} & =5 \cdot 5 \\
\mathrm{~m} & =+2\end{aligned}$ & $31 / 2$ & 63 & 93 \\
\hline 15 & 23 months & $122 . /-4$ & - & $\begin{aligned} a & =11 \\
v & =7 \\
m & =+7\end{aligned}$ & - & 72 & 98 \\
\hline 16 & 18 months & $110 / 0$ & - & $\begin{aligned} \mathrm{m} & =+ \\
\mathrm{a} & =5 \\
\mathrm{v} & =4 \\
\mathrm{~m} & =+4\end{aligned}$ & $80 / 0$ & 39 & 64 \\
\hline 18 & 5 months & $66 / 10$ & - & $\begin{aligned} \mathrm{m} & =+4 \\
\mathrm{a} & =13 \\
\mathrm{~m} & =+7\end{aligned}$ & - & 23 & - \\
\hline 19 & 9 days & $75 / 5$ & - & $\begin{array}{l}\mathrm{a}=16 \\
\mathrm{v}=9 \\
\mathrm{~m}=+9\end{array}$ & - & 19 & 76 \\
\hline $\begin{array}{l}22 \\
23\end{array}$ & $\begin{array}{l}3 \text { days } \\
7 \text { months }\end{array}$ & $\begin{array}{c}80 / 0 \\
74 / 20 \\
118 / 28\end{array}$ & 二 & $\begin{aligned} \mathrm{m} & =+6 \\
\mathrm{a} & =15 \\
\mathrm{~m} & =+11 \\
\mathrm{v} & =11\end{aligned}$ & 二 & $\begin{array}{l}16 \\
35\end{array}$ & $\begin{array}{l}97 \\
88\end{array}$ \\
\hline 25 & 13 months & $68 / 0$ & $18 / 8$ & $\begin{aligned} \mathrm{a} & =13 \\
\mathrm{~m} & =+5.5\end{aligned}$ & $68 / 0$ & 77 & 97 \\
\hline 26 & 26 days & $60 / 10$ & - & $\begin{aligned} \mathrm{a} & =12 \\
\mathrm{~m} & =+8\end{aligned}$ & $60 / 7$ & 32 & $\begin{array}{l}\text { L.V. } 52 \\
\text { L.A. } 97\end{array}$ \\
\hline
\end{tabular}

R.V. = right ventricle; R.A. = right atrium; P.A. = pulmonary artery; L.V. = left ventricle; F.A. $=$ femoral artery; L.A. $=$ left atrium $\mathrm{a}=\mathbf{a}$ wave in atrial trace; $\mathrm{v}=\mathrm{v}$ wave in atrial trace; $\mathrm{m}=$ mean pressure

plastic left kidney, and died at the time of operation at 6 weeks of age. All the deaths occurred within 48 hours of operation. Figure 12 shows the pre- and post-operative mortalities. Causes of death are shown in Tables $\mathrm{V}$ and VI.

The pulmonary valve in all cases was domed with fused cusps and a pin-hole orifice (Fig. 13). There was severe right ventricular hypertrophy, sometimes obliterating the right ventricular cavity, and right atrial enlargement (Fig. 14).

\section{T A B LE I V}

METHODS OF VALVOTOMY

\begin{tabular}{|c|c|c|c|c|}
\hline $\begin{array}{l}\text { No. of } \\
\text { Patients }\end{array}$ & Method & $\begin{array}{l}\text { No. of } \\
\text { Deaths }\end{array}$ & Year & Result \\
\hline 2 & $\begin{array}{l}\text { Profound hypothermia; } \\
\text { Supravalvular and in- } \\
\text { fundibular resection }\end{array}$ & 2 & 1961 & \\
\hline 1 & $\begin{array}{l}\text { Profound hypothermia } \\
\text { supravalvular }\end{array}$ & 1 & & \\
\hline 7 & Trans-ventricular (Brock's) & 5 & & $\begin{array}{ll}1 & \text { Good } \\
1 & \text { Fair }\end{array}$ \\
\hline 11 & $\begin{array}{l}\text { Supravalvular, with or } \\
\text { without surface cooling }\end{array}$ & None & $1962-67$ & All good \\
\hline
\end{tabular}

POST-OPERATIVE RESULTS The surviving 13 cases have all shown clinical improvement. Twelve patients are living a normal life 6 months to 6 years after operation. One patient is pink and active, but tires more easily than an average child. None has

T A B L E V

\begin{tabular}{|c|c|c|}
\hline Case No. & Age & $\begin{array}{l}\text { Cause of Death } \\
\text { (all within } 48 \text { hours post-op.) }\end{array}$ \\
\hline 6 & 6 months & $\begin{array}{l}\text { Severe right ventricular hypertrophy; } \\
\text { congestive cardiac failure }\end{array}$ \\
\hline 2 & 52 months & $\begin{array}{l}\text { Severe right ventricular hypertrophy; } \\
\text { congestive cardiac failure; } \\
\text { infundibular resection }\end{array}$ \\
\hline 5 & 1 month & $\begin{array}{l}\text { Severe right ventricular hypertrophy; } \\
\text { infundibular resection }\end{array}$ \\
\hline $\begin{array}{l}7 \\
9\end{array}$ & $\begin{array}{l}11 \text { months } \\
8 \text { months }\end{array}$ & $\begin{array}{l}\text { Endocardial fibroelastosis } \\
\text { Nephrotic syndrome; broncho- } \\
\text { pneumonia; anoxia }\end{array}$ \\
\hline 22 & $\begin{array}{l}3 \text { days } \\
9 \text { days }\end{array}$ & $\begin{array}{l}\text { Cardiac arrest following operation } \\
\text { Cardiac arrest following operation; } \\
\text { endocardial fibroelastosis }\end{array}$ \\
\hline 26 & 6 weeks & $\begin{array}{l}\text { Cardiac arrest at operation; } \\
\text { renal failure due to dysplastic } \\
\text { kidney; } \\
\text { severe congestive cardiac failure }\end{array}$ \\
\hline
\end{tabular}


cyanosis or any sign of cardiac failure. A residual systolic murmur is present in all but one patient. In most patients this is of the same intensity as before

T A B L E V I

\begin{tabular}{|c|c|c|}
\hline Case No. & $\begin{array}{c}\text { Age } \\
\text { (months) }\end{array}$ & Cause of Death \\
\hline $\begin{array}{r}3 \\
17 \\
13\end{array}$ & $\begin{array}{r}23 \\
6 \\
5\end{array}$ & $\begin{array}{l}\text { Angiography and cardiac arrest } \\
\text { Inhalation of gastric contents } \\
\text { Anoxic attacks and congestive cardiac } \\
\text { failure }\end{array}$ \\
\hline 21 & 17 & $\begin{array}{l}\text { Bronchopneumonia and congestive } \\
\text { cardiac failure }\end{array}$ \\
\hline 24 & 10 & $\begin{array}{l}\text { Anoxic attacks, acute suppurative } \\
\text { bronchitis and congestive cardiac } \\
\text { failure }\end{array}$ \\
\hline
\end{tabular}

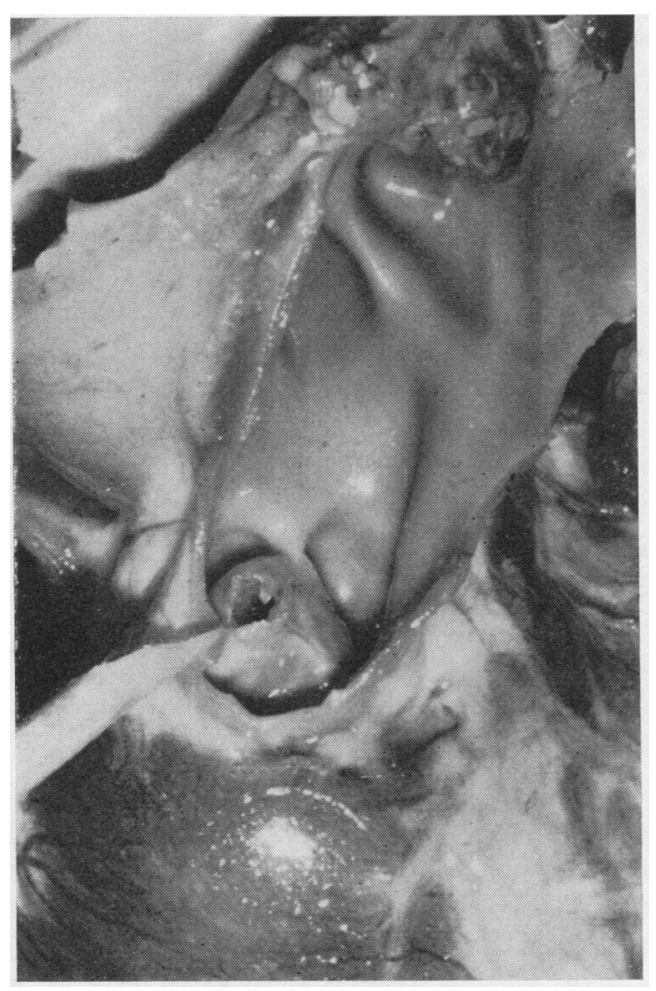

FIG. 13. Case 13. Post-mortem appearance of pulmonary valve showing the 'pin-hole' orifice in a 'domed' pulmonary valve. operation. Only three patients have a pulmonary diastolic murmur, without any disability. Tandon et al. (1965) and Gersony et al. (1967) have had similar findings.

Radiology Chest radiographs have improved considerably in all patients; eight are within normal limits (Fig. 4b) ; five still have a cardiothoracic ratio of between $50 \%$ and $60 \%$ and minimal oligaemia of the lung fields (Fig. 5b); five cases still show a prominent right atrium but smaller than before operation (Fig. 6b).

Electrocardiography All have shown improvement as demonstrated by reduction in right ventricular hypertrophy (Table II and Fig. 9b), shift of mean frontal QRS axis to the left (Fig. 10), and reduction in the height of $\mathbf{P}$ waves (Fig. 15). Post-operative electrocardiograms of case 16 exemplify these improvements (Fig. 8b). Maximal electrocardiographic improvement was usually evident by about six months post-operatively.

Haemodynamic studies Four patients have been recatheterized after operation and all showed haemodynamic improvement (Table VII). Of these, cases 1 and 4 have haemodynamic findings within normal limits; case 11 still has evidence of mild pulmonary stenosis and case 14 of moderate pulmonary stenosis.

\section{DISCUSSION}

Our results demonstrate that severe pulmonary stenosis with intact ventricular septum in the first two years of life is a grave condition and leads rapidly to death unless it is recognized early and treated promptly. Johnson and Johnson (1952), Gibson et al. (1954), Mustard et al. (1960, 1968), Luke (1966), and Gersony et al. (1967) have reached similar conclusions.

The clinical features are usually characteristic and a diagnosis can be made with the aid of electrocardiogram and chest radiograph. Like Gersony et al. (1967) we find that the electrocardiogram is the most useful tool in the diagnosis and differentiation of this condition from other causes of cyanotic heart disease in infancy. However, it is desirable to confirm the diagnosis by cardiac catheterization and selective angiocardiography. If the infant is deteriorating rapidly

T A B LE V I I

POST-OPERATIVE CATHETERIZATION DATA

\begin{tabular}{|c|c|c|c|c|c|c|c|c|}
\hline \multirow{2}{*}{ Case No. } & \multirow{2}{*}{$\begin{array}{c}\text { Age at } \\
\text { Operation } \\
\text { (months) }\end{array}$} & \multirow{2}{*}{$\begin{array}{l}\text { Age at } \\
\text { Catheter- } \\
\text { ization } \\
\text { (months) }\end{array}$} & \multicolumn{4}{|c|}{ Pressures } & \multicolumn{2}{|c|}{ Oxygen Saturation $\%$} \\
\hline & & & R.V. & P.A. & R.A. & L.V. or F.A. & Mixed Venous & Arterial \\
\hline $\begin{array}{r}1 \\
4 \\
11 \\
14\end{array}$ & $\begin{array}{l}17 \\
2 \frac{1}{2} \\
33 \\
22\end{array}$ & $\begin{array}{l}38 \\
13 \\
50 \\
40\end{array}$ & $\begin{array}{l}28 / 0 \\
33 / 0 \\
46 /-3 \\
60 / 0\end{array}$ & $\begin{array}{l}- \\
3 \overline{5 / 2} \\
15 / 5\end{array}$ & $\begin{array}{l}\mathrm{m}=2 \cdot 5 \\
\mathrm{~m}=2 \\
\mathrm{~m}=2 \\
\mathrm{~m}=4\end{array}$ & $\begin{array}{l}\overline{62 / 0} \\
- \\
-\end{array}$ & $\begin{array}{l}70 \\
58 \\
63 \\
67\end{array}$ & $\begin{array}{l}95 \\
96 \\
95 \\
93\end{array}$ \\
\hline
\end{tabular}




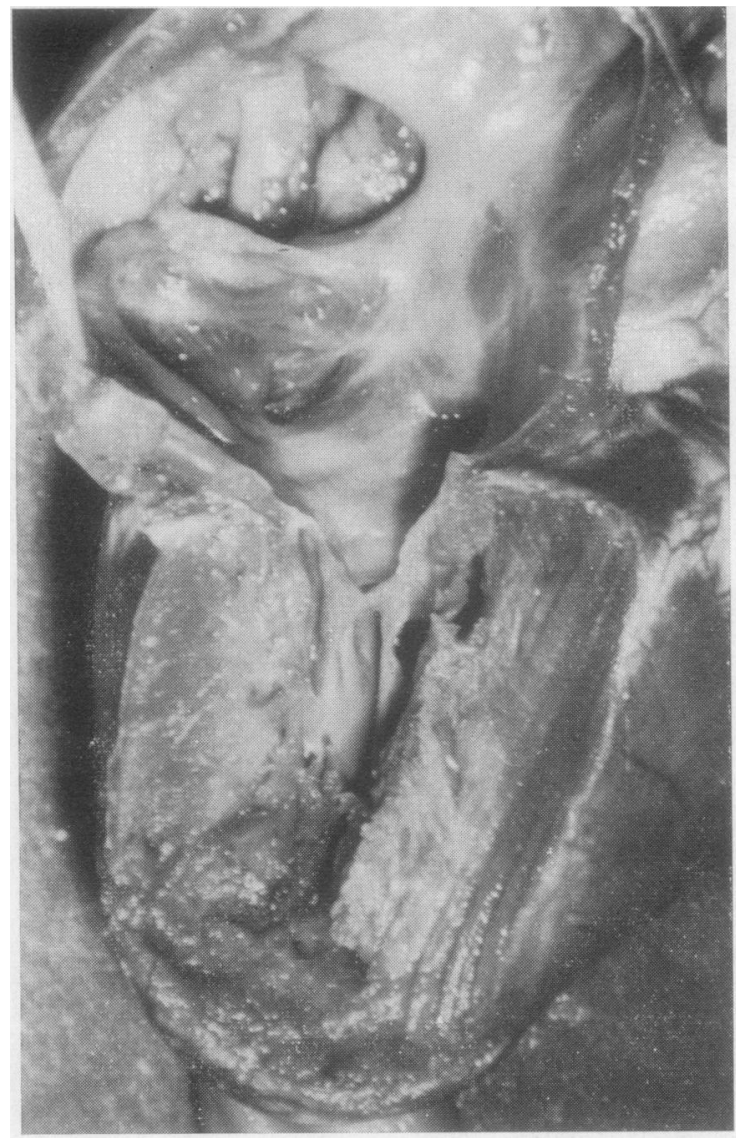

FIG. 14. Case 13. Post-mortem appearance of heart showing a very hypertrophied right ventricle and a dilated right atrium.

valvotomy must be done as an emergency without further investigations. The indications for prompt valvotomy are:

1. Progressive cyanosis and dyspnoea

2. Congestive cardiac failure

3. Hypoxic spells

4. Failure to thrive and feeding difficulties

5. Marked polycythaemia

6. Electrocardiographic findings of

(a) severe right ventricular hypertrophy

(b) right axis deviation

(c) right atrial hypertrophy

7. Radiological evidence of :

(a) cardiac enlargement

(b) pulmonary oligaemia

8. Haemodynamic evidence of :

(a) right ventricular pressure equal to or higher than the systemic pressure (b) high right ventricular end-diastolic pressure of more than $12 \mathrm{~mm} . \mathrm{Hg}$

(c) right-to-left inter-atrial shunt

(d) a pin-hole pulmonary valve orifice giving 'a narrow jet' on the angiocardiogram.

In this centre five patients died before operation could be performed (Table VI). One patient (case 26), whose operation was delayed for one week due to uncertainty of diagnosis, deteriorated rapidly and developed severe cardiac failure. Cardiac arrest occurred during induction of anaesthesia for emergency valvotomy. Another patient (case 9) died soon after valvotomy, having been referred with the nephrotic syndrome and in advanced cardiac failure.

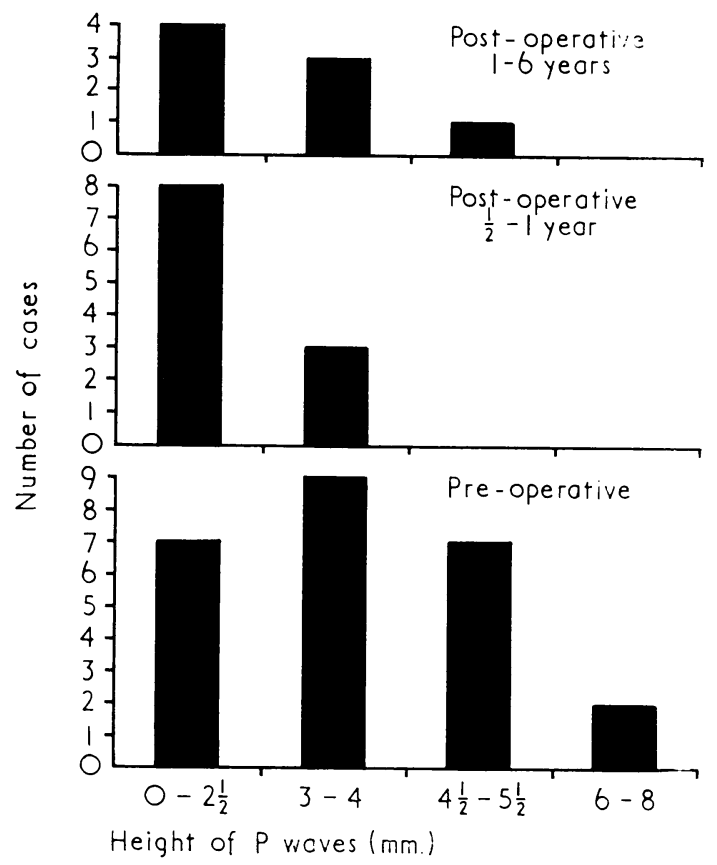

FIG. 15. Height of 'P' waves before and after operation.

The patients fall into two main groups: those $\underset{\mathcal{O}}{ }$ whose symptoms began before 2 weeks of age, $\mathbb{\omega}$ deteriorated rapidly, and had a higher operative mortality; and those whose symptoms began after $\theta$ 4 months (when the infant becomes physically $\mathbb{D}$ more active) and deteriorated relatively slowly. In the first group presentation is typically with a dusky grey cyanosis and tachypnoea in the first two weeks of life with an enlarged globular heart. Deterioration is rapid. The electrocardiogram may $\mathbb{Q}$ show little right ventricular hypertrophy, e.g. O cases 7 and 22. The second group develops 
cyanosis and/or congestive cardiac failure at a few months of age. The babies in this group are usually well developed. Some may present with little disability but with signs of severe pulmonary stenosis and right ventricular hypertrophy and strain, e.g., cases 15 and 21. Their appearance of well being may prove fatal if operation is delayed (case 21). Case 9 also had no cyanosis when seen at 8 months of age, but there was gross oedema and ascites. He was found to have the nephrotic syndrome and evidence of severe pulmonary stenosis. Consciousness was rapidly lost and emergency transventricular valvotomy was performed. Chest radiographs post-operatively showed improvement, but he did not regain consciousness and died the following day. At necropsy severe pulmonary valve stenosis and extreme capillary congestion and cloudy swelling of the renal convoluted tubules were found. The foramen ovale was sealed.

The nephrotic syndrome in association with congestive cardiac failure, and with congenital heart lesions, has been reported previously (Burack, Pryce, and Goodwin, 1958; Thayer, Gleckler, and Holmes, 1961 ; Drummond, Vernier, Worthen, and Good, 1963). Most adult patients in other series had been treated with mercurial diuretics, but there were also patients who had not had this treatment. Case 9 in our series had not been treated with mercurials. If an increased right heart pressure and diminished systemic venous return would account for the nephrotic syndrome then presumably the closure of the foramen ovale could account for absence of cyanosis and aggravate a raised right atrial and vena caval pressure. In other words, a patent foramen ovale has a safety valve function in severe pulmonary stenosis. Eighteen of our patients had a patent foramen ovale. In three patients the foramen was definitely sealed at necropsy, and in one patient attempts to pass a catheter through the foramen failed. This patient had clinical tricuspid incompetence and raised right atrial pressure. In the other four cases no conclusion could be drawn about the patency of the foramen.

Two infants (cases 7 and 20) had right ventricular endocardial fibroelastosis. Gersony et al. (1967) also report two cases of endocardial fibroelastosis among their 19 infants with pulmonary stenosis. Our two patients were both operated on promptly by the transventricular method, at 8 days of age (case 20) and at 1 month (case 7). Case 20 died immediately after operation. Case 7 survived operation, with some improvement, but died after a second operation a year later. She also had a diminutive right ventricle.

Cardiac catheterization in these infants does not always give an accurate assessment of pulmonary valve stenosis. The pulmonary artery often cannot be entered due to the severity of the stenosis, besides which an attempt to pass a catheter through a pin-hole valve orifice may prove hazardous. The right ventricular pressure and the systolic gradient across the pulmonary valve do not always accurately represent the severity of the stenosis. Case 14 with very severe stenosis and cardiac failure at 2 months of age had a right ventricular pressure of $36 / 0$ but the left ventricular pressure was only $31 / 2$. This pattern was also present in case 10 . This is probably due to cardiac failure and anaesthesia. Therefore the ratio of right ventricular pressure to systemic pressure is a more important criterion for assessing the degree of stenosis than right ventricular pressure alone. This is evident in nine other cases in whom the systemic blood pressure was also measured at cardiac catheterization. This would also account for the fact that in our series, as with that of Gersony et al. (1967), the height of $R$ in $V_{1}$ or the anatomical severity of stenosis had no correlation with right ventricular pressure, unlike in older age groups (Cayler, Ongley, and Nadas, 1958).

Our method of choice for valvotomy is direct vision supravalvular pulmonary valvotomy with circulatory arrest under normothermia, if the pulmonary artery and ring is big enough for this procedure. The more severe the stenosis the easier it is to relieve under direct vision. This can be accomplished in less than 3 minutes with accurate division of the commissures. Moreover, the myocardium is not weakened by a surgical incision. In very young babies, however, with a small pulmonary artery and ring the transventricular method is preferred. In our experience, infundibular resection is unnecessary. When carried out it only weakens the right ventricle without relieving the obstruction which is due to total hypertrophy of this chamber. We agree with Engle, Holswade, Goldberg, Lukas, and Glenn (1958) that in time the hypertrophy regresses.

Pulmonary valvotomy under direct vision using pulmonary bypass has been used in other centres with satisfactory results (Gerbode, Ross, Harkins, and Osborn, 1960 ; Tandon et al., 1965). Berman, Linde, and Mulder (1965) recommend a staged repair of pulmonary stenosis in infants with a hypoplastic right ventricle. Dilley et al. (1963) have carried out an evaluation of the clinical 
results of various methods of pulmonary valvotomy.

The authors wish to thank the following persons for their valuable advice and assistance: Mr. Charles E. Drew ; Dr. P. R. Fleming ; Dr. C. Newman ; Dr. B. Strickland and the Radiology Department ; Dr. P. Cliffe and the Department of Clinical Measurement ; Dr. P. Hansell and the Photographic Department; and finally Mrs. M. Nairn for her excellent secretarial assistance.

These patients were operated on by Mr. Charles E. Drew.

\section{REFERFNCES}

Abrahams, D. G., and Wood, P. (1951). Pulmonary stenosis with normal aortic root. Brit. Heart J., 13, 519.

Allanby, K. D., and Campbell, M. (1949). Congenital pulmonary stenosis with closed ventricular septum. Guy's Hosp. Rep., 98, 18

Benton, J. W., Elliott, L. P., Adams, P., Anderson, R. C., Hong, C. Y. and Lester, R. G. (1962). Pulmonary artesia and stenosis with intact ventricular septum. Amer. J. Dis. Child., 104, 161.

Berman, G. D., Linde, L. M., and Mulder, D. G. (1965). Staged repair of pulmonary stenosis and hypoplastic right ventricle. Arch. Surg., 91, 597.

Eraimbridge, M. V., Oakley, C. M., Bentall, H. H., and Cleland, W. P. (1966). Pulmonary valve stenosis without ventricular septal defect: results of surgery. Thorax, 21, 164.

Brock, R. C. (1948). Pulmonary valvulotomy for the relief of congenital pulmonary stenosis. Brit. med. J., 1, 1121.

- (1949). The surgery of pulmonary stenosis. Ibid., 2, 399.

- (1961). The surgical treatment of pulmonary stenosis. Brit. Heart J., 23, 337.

Burack, W. R., Pryce, J., and Goodwin, J. F. (1958). A reversible nephrotic syndrome associated with congestive heart failure. Circulation, 18, 562 .

Cayler, G. G., Ongley, P., and Nadas, A. S. (1958). Relation of systolic pressure in the right ventricle to the electrocardiogram. A study of patients with pulmonary stenosis and intact ventricular septum. New Engl. J. Med., 258, 979.

Dilley, R. B., Longmire, W. P., and Maloney, J. V. Jr. (1963). An evaluation of the clinical results in the surgical treatment of isolated valvular pulmonary stenosis by the closed transventricular, hypothermic, and cardiopulmonary bypass techniques. J. thorac. cardiovasc. Surg., 45, 789.
Drummond, K. N., Vernier, R. L., Worthen, H. G., and Good, R. A. (1963). The associated occurrence of the nephrotic syndrome and congenital heart disease. Pediatrics, 31, 103.

Engle, M. A., Holswade, G. R., Goldberg, H. P., Lukas, D. S., and Glenn, F. (1958). Regression after open valvotomy of infundibular stenosis accompanying severe valvular pulmonic stenosis. Circulation, 17, 862.

- Ito, T., and Goldberg, H. P. (1964). The fate of the patient with pulmonic stenosis. Ibid., 30, 554 .

Gerbode, F., Ross, J. K., Harkins, G. A., and Osborn J. J. (1960) Surgical treatment of pulmonary stenosis using extracorporeal circulation. Surgery, $48,58$.

Gersony, W. M., Bernhard, S. F., Nadas, A. S., and Gross, R. E. (1967). Diagnosis nd surgical treatment of infants with critical pulmonary outflow obstruction. Circulation, 35, 765.

Gibson, S., White, H., ohnson, R., and Potts, W. J. (1954). Congenital pulmonary stenosis with intact ventricular septum. Amer.J. Dis. Child., 87, 26.

Hardy, J. D., Timmis, H. H., Webb, W. R., Watson, D. G., and Blake, T. M. (1966). Isolated pulmonic stenosis: surgical results in 26 cases. Surgery, 60, 980.

Johnson, R. P., and Johnson, E. E. (1952). Congenital pulmonary stenosis with open foramen ovale in infancy. Amer. Heart J., 44, 344 .

Lillehei, C. W., Simmons, R. L., and Todd, D. B. (1965). Late hemodynamic response to correction of isolated pulmonary stenosis by open operation during pulmonary bypass. Circulation, 32, 258.

Luke, M. J. (1966). Valvular pulmonic stenosis in infancy. J. Pediat., 68, 90 .

Moller, J. H., and Adams, P. (1965). The natural history of pulmonary valvular stenosis. Serial cardiac catheterizations in 21 children. Amer. J. Cardiol., 16, 654.

Mustard, W. T., Rowe, R. D., and Firor, W. B. (1960). Pulmonic stenosis in the first year of life. Surgery, 47, 678.

- Jain, S. C., and Trusler, G. A. (1968). Pulmonic stenosis in the first year of life. Brit. Heart J., 30, 255.

Nadas, A. S. (1963). Pediatric Cardiology, 2nd ed., W. B. Saunders, Philadelphia and London.

Tandon, R., Nadas, A. S., and Gross, R. E. (1965). Results of openheart surgery in patients with pulmonic stenosis and intact ventricular septum. A report of 108 cases. Circulation, 31, 190

Thayer, J. M., Gleckler, W. J., and Holmes, R. O. (1961). The development of the nephrotic syndrome during the course of congestive cardiac failure. Ann. intern. Med., 54, 1013.

Williams, J. C. P., Barratt-Boyes, B. G., and Lowe, J. B. (1963) Underdeveloped right ventricle and pulmonary stenosis. Amer. J. Cardiol., 11, 458. 